\title{
When Women's Football Came to the Island
}

\author{
Stuart Gibbs \\ B.A. Honors in Fine Art \\ Volunteer researcher for University of Kent \\ Canterbury, UK
}

(c) Stuart Gibbs. This work is licensed under the Creative Commons Attribution-NonCommercial-

NoDerivatives 4.0 International License. To view a copy of this license, visit

http://creativecommons.org/licenses/by-nc-nd/4.0/.

\begin{abstract}
This article looks at the early development of women's football in Ireland, examining the cultural impact of the first women's matches, and how this early heritage has laid foundations for future developments. Women took to playing association football not long after it was first established as a male bastion during the latter half of the nineteenth century. These early matches attracted large crowds, public and press criticism, and in some instances social disorder. The article first examines how the Irish press presented this sporting innovation and the first exposure to actual matches when the British Ladies Club arrived to play in Belfast in early June 1895. Beyond the expected disapproval, there is evidence that debate took place on women's general role in society, and in particular how females could engage in sport. Also examined is the way British Ladies Club presented themselves as upper-middle-class, and how this contrasted with the way they were portrayed in the press. New research is presented, which casts doubt on the club's middle class image and shows how friction between the club and its main sponsor arose when a true picture of the players' back-grounds came to light. In conclusion, the author contrasts the Irish response to the British Ladies Football Club with the women's sides that played during World War I and the post-war period. It is shown that the early matches of the 1890s paved the way for a more appreciative and accepting audience.
\end{abstract}

Keywords: Women's football; Ireland; Popular press; British Ladies Football Club; Football and culture

\section{Introduction}

10 May 2020, marked the fiftith anniversary of Dundalk Ladies' journey to Wales to play against the Manchester Corinthians. Dundalk Ladies formed in 1968 as an off-shoot of the work-place indoor soccer leagues popular in Ireland during the late 1960s. ${ }^{1}$ Dundalk often played their matches before the men's League of Ireland games. For the match held at the Prestatyn Harness Race Stadium in Wales Dundalk were pitted against the foremost side in England, the Corinthians Nomads and the fixture was promoted as an Ireland $v$. England match. ${ }^{2}$ Dundalk had a torrid time in Prestatyn but this match has been credited as kick-starting women's football in Ireland.

\footnotetext{
${ }^{1}$ Helena Byrne, "How it all began: the story of women's soccer in sixties Drogheda", Soccer \& Society 18, 26 September 2016, 709, doi:10.1080/14660970.2016.1230343. Accessed 22 September 2020.

${ }^{2}$ Suzanne Wrack, "We were shocked, stunned: 50 Years since Dundalk v Corinthians Nomads", Guardian ,12 May 2020, https://newstral.com/en/article/en/1151929549/-we-were-shocked-fifty-years-since-dundalk-vcorinthians-nomads. Accessed 12 October 2020.
} 
It is tempting to suggest that the story begins here. The origins of the game in Ireland, however, dates back to the arrival of the British Ladies Football Club in 1895. Two exhibition matches were played in Belfast during the spring of 1895 followed a large-scale tour in 1896. Soccer was only introduced to Ireland in the mid-1870s with a prominent early match played at the Ulster Cricket Ground featuring Scottish sides, Caledonian and an ad-hoc Queens Park. The interest generated led to the formation of Cliftonville in 1879 with early matches played to Scottish Football Association rules. ${ }^{3}$ The image presented of the British Ladies Football Club was that of middle-class ladies of leisure emphasised by a panel of caricatures published in the Sketch and numerous interviews given by club members. ${ }^{4}$ Many myths and legends have developed around the main protagonists, Nettie Honeyball, Mrs Graham and Lady Florence Dixie. In the course of this paper, many of these myths are deconstructed. ${ }^{5}$

This article will go behind the scenes to examine the internal workings of the club and give a truer picture of the player's background. It will also focus on how the image and projection of the organisation caused internal friction that developed within the club structure. In years following the visit of the British Ladies club women's football established itself especially during the Great War period with indigenous sides forming. This carried on into the 1920s and 1930s and in conclusion I contrast the response to the women's side of the World War 1 and post war period and how those early matches of the 1890s paved the way for a more appreciative and accepting audience.

\section{Women's Sport in Ireland and the Origins of Women's Soccer}

References to women playing sports in Ireland date from the eighteenth century, and by the mid-nineteenth century they were fully engaged in sport activities to the extent that they would regularly feature in press reports. One of the early activities women were involved with was Crooky, later known as croquet. Thought to have been brought to Ireland in the late eighteenth century by French refugees, this game began in rural areas of Ireland such as Oatlands and Newcastle County Meath and Greenmount near Castlebellingham, County Louth. ${ }^{6}$ By the middle of the nineteenth century numerous croquet clubs were operating across Ireland and were introduced into England in the 1850s. Another lawn based sport, tennis, was taken up enthusiastically by women with participants drawn mostly from privileged backgrounds. ${ }^{7}$ Tennis was a major feature in Irish life during the later decades of the nineteenth century. The inaugural Irish Championship won by May Langrishe at the Fitzwilliam Tennis \& Croquet Club in 1879, was one of the four main tournaments of the era - the others being Wimbledon, the Northern and US Championships. ${ }^{8}$ Cricket was also played by women in Ireland and was part of the social life of the large houses. One match played in 1887 at Killashee the home of Major Richard St Ledger Moore, featured the tennis players Louise Martin and Mabel Esmonde Cahill winner of the US Championships in 1891 and $1892 .^{9}$

\footnotetext{
3 "Football", Northern Whig, 6 November 1878, 8.

4 "The Lady Footballers, An Anticipation", The Sketch, 24 October 1894, 33.

5 Patrick Brennan theorised that Jessie Allan, wife of British Club official, Frederick Smith was the true identity of Nettie Honeyball. Jessie Allan Smith was club secretary in the autumn of 1895 and also played in matches. This theory has yet to be confirmed, but an interesting idea worthy of further investigation.("Nettie Honeyball", The British Ladies' Football Club, http://www.donmouth.co.uk/womens football/nettie honeyball.html accessed 20 September 2020)

${ }^{6}$ James Charlton and William Thompson, "Croquet: Lore \& Legend", Oxford Croquet, (2004): https://www.oxfordcroquet.com/history /american/index.asp. Accessed 20 September 2020.

7 "Lawn Tennis at Norelands", Kilkenny Moderator, 20 September 1879, 3.

8 "Ladies Chit Chat, by Eva", Richmond \& Rippon Chronicle, 19 July 1890, 6.

9 "Ladies Cricket Match", Kildare Observer, 16 July 1887, 5.
} 
Women's sport found a place in the developing education system. In 1866 the prominent educationist Ann Jellicoe founded the Alexandra College in Milltown near Dublin, as an extension of the Society for Promoting the Employment of Women. ${ }^{10}$ A more formal system for the education of girls was one of the goals for the social reformer Isabella M. S. Tod. She had presented the paper 'Higher Education of Women' to the National Association for the Promotion of Social Science in 1867 and was part of the delegation which successfully lobbied Lord Cairns to amend the 1878 Intermediate Education (Ireland) Act to include girls. ${ }^{11}$ A net result was that of the 7,000 pupils put forward in 1881 for examination 2,000 were female and from Ireland's growing middle class. The provision that was made for the more impoverished children, from poor law authorities and religious societies, made little room for physical education outside of rudimentary drill. ${ }^{12}$ The game most promoted for girls in the public schools and colleges was hockey. Students at the Alexandra College were encouraged to take up the sport after attending a lecture given by the Irish artist and horticulturalist Frances Currie in which she hailed hockey as an ideal outdoor game for girls. The rapid growth of hockey led to the formation of the Irish Hockey Union in 1894. An 1896 article for a London paper summarised progress within Irish women's sports: 'tennis and cricket have paved the way for hockey and, once some old-world prejudices were removed, parents, guardians, and heads of schools became warm advocates of the game'. ${ }^{13}$

The origins of women's football are in stark contrast. Early matches were part of village life with participants drawn from menial labour or intensive industries. A recent project Mapping Irish Football has been chronicling the various football codes as reported in the press. ${ }^{14}$ The Mapping Project identified an early reference to women playing football in Scotland, which appeared in the Meath Herald of 22 February 1879. This article on holiday traditions, made reference to the annual married v singles matches played by the fish workers of the Midlothian village of Inveresk. ${ }^{15}$ The account was taken from the Statistical Account of Scotland for 1795, which notes that the married women usually won. The Meath Herald described the venue for these encounters as Inverness County; an error that would be repeated in publications stretching into the twentieth century. ${ }^{16}$ During the 1870 s women were given free access to football matches and it is likely that girls and young women were in attendance. There is also a strong indication that football was played among working class and impoverished girls. In a libel case against William Shaen over his pamphlet on conditions in the Lambeth Workhouse, Elizabeth Wilson, assistant matron of the workhouse noted in her evidence:

When Mr. Catch first came to the house, he found the place in great confusion. The master who was there before him used to let the young men and girls play at football, and after that if Mr. Catch only looked at them he was thought most cruel. ${ }^{17}$

The Hamilton Advertiser in 1873 chronicled the Turfholm Woman's Industrial School's annual summer treat to the residence of Mr \& Mrs McKirdy. Football and other games were played that day for the benefit of the school's benefactors which included Dr \& Mrs Adams, Miss F.

\footnotetext{
10 "The Alexandra College", Mayo Constitution, 2 October 1866, 4.

11 "The Death of Miss Isabella M.S. Tod”, Northern Whig, 9 December 1896, 5.

12 Kathleen McCrone, "Class Gender and English Women's Sports c. 1890 - 1914”, Journal of Sports History,

18, no 1 (Spring 1991): 161.

13 "Ladies as Hockey Players", The Sketch, 22 July 1896, 26.

${ }^{14}$ Helena Byrne, "Mapping Irish Football”, The Newsroom Blog, British Library, 11 June 2020,

https://blogs.bl.uk/thenewsroom/2020/06/mapping-irish-womens-football.html. Accessed 22 September 2020.

15 "Pancake Day", Meath Herald \& Cavan Advertiser, February 22, 1879, 3.

16 "Of Inveresk", Statistical Account of Scotland, XVI, 1795, 19.

https://stataccscot.edina.ac.uk/static/statacc/dist/viewer/osa-vol16-

Parish_record for_Inveresk in the county_of_Edinburgh_in_volume_16_of_account_1/. Accessed 7 May

2020.

17 “The Extraordinary Case of Libel, Catch v Shaen”, Clerkenwell News, 2 December 1870, 4.
} 
Lockheart and Reverent McNaughton. Industrial Schools were designed for the urban poor, vulnerable young people who were likely to end up before the magistrates. Similar evidence relating to Ireland has yet to be found, but that football should be played at such an institution indicates that the game was not unknown among young working class girls. ${ }^{18}$

The birth of women's association football was quite removed from genteel society. In 1881, a group consisting of the Edinburgh-born theatre entrepreneur Alec Gordon, Charles Scholes of the Blackburn Theatre Royal and Charles Imbert a manager for one of Scholes syndicated theatres organised the first matches. ${ }^{19}$ The motive was largely to raise funds for Charles Scholes's theatre empire, which had gone into liquidation during 1880 with the consortium's first match, held in Edinburgh at Easter Road on May 7 1881. The sides were titled as 'Scotland' and 'England' with the 'Scottish' side winning 3-0. ${ }^{20}$

With Glasgow's football fraternity uncooperative, the next fixture took place at the Shawfield running track in Rutherglen. The match ended in a pitch invasion and negative press reports led to a court order being placed on subsequent matches. ${ }^{21}$ As a result of this, further fixtures were played in Blackburn, Bradford and Sheffield during June of 1881. Much of the press for these matches reflects the idea that women's participation would somehow corrupt the game and that Association football was 'a manly sport which honour requires to be kept amongst men'. ${ }^{22}$ Reports of the matches appear in the Irish press not to mention many overseas papers, such as The Times of India, the New York Sun, the New Zealand based Hawks Herald and the Sidney Evening News. The reports, however, are examples of scissors and paste journalism: one of the main articles is credited to the Scotsman, and the text matches an article printed in that paper on 9 May 1881. Other publications such as the Glasgow Evening News and Blackburn Standard can be identified as primary sources for the reports. Material not originally published also found its way into the press, including gossip from telegraph communications and off the record comments. The Pendleton Times noted that that a number of players taking part in the Edinburgh match had 'the appearance of ballet dancers' ${ }^{23}$ This was supported by the Irvine Times who had it on good authority that many in the squad were ballerinas. ${ }^{24}$ The Belfast Telegraph put its own slant on the events but voiced, uncritically, the view that football was not an acceptable sport for women:

Much as such a display, conducted for the purposes of profit, is to be condemned, it is perhaps no more out of keeping with feminine modesty than land League stumping. ${ }^{25}$

The Irish Weekly News on 23 October 1886 announced the formation of a women's football side, but was unsure if they would play to association or rugby rules. The location for this activity is also unclear but the report may refer to Madame Wills's side which formed in Grimsby during 1886. The organisers appeared to be the business manager of the Hull Alhambra, George Soule, the stage actor Peter Bridges, and a circus performer, Albert Wells. ${ }^{26}$ A similar paragraph appeared in several newspapers on the mainland UK with the Hull Daily Mail the obvious candidate to have produced the original article, but archived issues of this newspaper are only available from January to June 1886 and so the original source has yet to be established. M.H. Beals explained the problems which may arise locating the exact source of an article in a blog post in 2020:

\footnotetext{
18 "Lesmahagow", Hamilton Advertiser, 30 August 1873, 2.

19 "Athletic Jottings", Glasgow Evening News, 21 May 1881, 4.

20 "Women's Football Match", Carlow Sentinel, 21 May 1881, 4.

21 "Prohibition of the Lady Players", Carlow Sentinel, 28 May 1881, 4.

22 Jean Williams, A Beautiful Game (Oxford: Berg, 2007): 111.

23 "Football", Pendleton Times \& Reporter, 14 May 1881, 6.

24 "The 'Lady' Football Players", Irvine Times, 21 May 1881, 5.

25 “What Next?”Belfast Telegraph, 10 May 1881, 3.

26 “The Ladies Football Match", Hull Daily Mail, 11 April 1887, 4.
} 
As with any preservation project, the costs associated with digitisation have led to the subjective selection of popular, representative or historically important titles from an already reduced catalogue of surviving hard-copy newspapers. Likewise, even if a newspaper has been selected for preservation, multiple editions and non-surviving issues mean that true certainty will always remain elusive, even with manual examination. ${ }^{27}$

Women's football was seen, in some quarters, as another encroachment into the male world. That is how the Carrickfurgus Advertiser viewed the formation of a club in Auckland, New Zealand 1891. It was not clear which code the sides were to play, rugby or association, and because the venture folded a few months after it was established the New Zealand public were never able to judge the merits of the club for themselves. ${ }^{28}$ A ladies $v$ gentlemen match played as part of a cycling event held in the C.K.A.A. Grounds at Tralee, County Kerry on 4 May 1893. The Kerry Evening Post references the match in their account of the event but gaves little detail about the participants. The report's description of one the teams as 'Ladies' seems to suggest the side were males dressed in female clothes, perhaps theatre performers brought in to give light entertainment. ${ }^{29}$ Actual women's football events didn't happen in Ireland until the spring of 1895, with the announcement that the British Ladies Football Club would play matches in Belfast.

\section{The British Ladies Football Club}

The British Ladies were formed in the autumn of 1894 by the Smith family of 27 Weston Park, North London. Alfred Hewitt Smith, older brother Frederick, wife Jessie, Hewitt Smith's own wife Hannah Oliphant and younger sister Phoebe ran the club. ${ }^{30}$ The focus of press attention were the club's two figureheads Nettie Honeyball and Mrs Graham. In one interview Honeyball attempted to present the playing squad as ladies of privilege:

They are all educated young ladies and belong to what I term the upper-middle-class. They are mostly all from different parts of London, but we have one from the north. If I accepted all the girls from the masses that made application to join us, why, our list would have been filled long ago. ${ }^{31}$

Football, at this time, was considered a sport for the lower classes and in an attempt to gain the kind of respectability given to other women's sports the players of the British Ladies Football Club put great emphasis onto their image of respectable middle-class women. ${ }^{32}$ The club were also keen to attract sponsorship and the Nettie Honeyball figurehead was used to great effect to attract the support of Lady Florence Dixie. Lady Florence was presented as the British Ladies' President and in early January, and besides this exposure the club benefited from financial backing.

\section{Lady Florence Dixie as President}

Born in 1855, Florence Douglas Dixie, was the daughter of the parliamentarian Archibald William Douglas, 7th Marques of Queensbury and was brought up on the Kinmount Estate near Annan in Dumfriesshire, Scotland. She first came to prominence with the travelogue Riding Across Patagonia (1880), and was also politically active; involved with Home Rule for

\footnotetext{
${ }^{27}$ M. H. Beals, "Flips and Clicks, Musings on Multimodal Analysis of Scissors and Paste Journalism”, 1 June 2020, https://mhbeals.com/multimodal/ Accessed 30 September 2020.

28 "Lady Footballer", Carrickfurgus Advertiser, 21 August 1891, 2.

29 "Evening Sports at Tralee", Kerry Evening Post, 6 May 1893, 3.

30 "Football", East Anglian Times, 30 November 1896, 4.

31 "Lady Football Players at Maidenhead", Maidenhead Advertiser, 17 April 1895, 6.

${ }^{32}$ Lisa Jenkel, "The FA's ban on women's football 1921 in the contemporary press - a historical discourse analysis", Sport in History, February 20, 2020, 6.

https://www.tandfonline.com/doi/full/10.1080/17460263.2020.1726441 Accessed 10 October 2020.
} 
Scotland and Ireland as well as woman's rights. ${ }^{33}$ Speaking at a conference in Glasgow in 1891 , Lady Florence declared that she 'hoped before she died to stand in parliament'. Interestingly Nettie Honeyball paraphrased this comment in an interview during February of $1895 .{ }^{34}$

Florence Dixie took a particular interest in sport, but was reluctant at first to get involved with the British Ladies. Her main concerns were the dress of the players, and the name: 'British' should replace the original title English Ladies Football Club. When these issues were ironed out Lady Florence was duly presented as the club president. In a column for the Pall Mall Gazette on 8 February 1895, titled 'Football for Woman', Lady Florence set out her manifesto for football as a vehicle for woman's development:

Football is the sport for woman, she concluded 'the pastime of all others which will ensure health and assist in destroying that hydra-headed monster, the present dress of woman. ${ }^{35}$

Florence Dixie was a popular figure in Ireland, in part for her views on Home Rule but also for her fund raising efforts for the Irish west coast cottiers and small farmers in autumn of 1882 . She was also critical of the Irish Land League and the limited support they gave the west coast land workers. Lady Florence was attacked outside her Windsor residence in March 1883, and the Land League was blamed for orchestrating the incident in retaliation for Dixie's criticism. ${ }^{36}$ This caused a stir in Ireland and it was noted of letters of sympathy, in the aftermath of the incident, that a large proportion came from Ireland. The club were quick to make full use of this situation in their publicity.

\section{The club and its membership}

Ahead of the player's arrival in Belfast, the Northern Whig helpfully published brief biographies of the participants. ${ }^{37}$ Nettie Honeyball had left the club in May 1895, due to either injury or illness and in her absence; Mrs Graham was presented as the club's captain, attracting a large amount of press attention. The Northern Whig stated that she was the only Scottish player in the squad, born in Montrose. Mrs Graham's real name was Helen Matthew and was born in London in 1871 and later brought up in Littleham, Devon. ${ }^{38}$ Despite the name 'Mrs Graham', she was not actually married. Matthew's involvement in football also stretched to journalism. Working with sister Florence as the 'Lothian Lassies', contributed sports columns to the Lancashire Daily Post and the Football and Cricket Field. Helen Matthew contributed artwork for these columns; she also produced illustrations featuring British Ladies club members which appeared in the press during $1895 .{ }^{39}$

The Northern Whig article of June 1895 provides a starting point to research the player's backgrounds using birth records and census returns. The picture presented, however, is far removed from the crafted image projected by the club. For instance, Ellen (Nellie) and May Hudson from Newcastle were daughters of a coachman Robert Hudson. ${ }^{40}$ May Hudson was fourteen when she came into the side as a replacement for the departing Nettie Honeyball. Hannah Oliphant was the daughter of James Oliphant, a boiler-maker from Washington, County Durham. Florence Beatrice Fenn was brought up above the General Havelock Inn on

\footnotetext{
33 "The Family of Lady Florence Dixie", Edinburgh Evening News, 21 March 1883, 4.

34 "Lady Florence Dixie in Glasgow", Glasgow Herald, 22 Apri 1891, 11.

${ }^{35}$ Lady Florence Dixie, "Football for Women", Pall Mall Gazette, 8 February 1895, 5, 6.

${ }^{36}$ T. M. Healy, "Letters and Leaders in My Day", Sligo Champion, 23 August 23 1933, 8.

37 "Lady Footballers in Belfast", Northern Whig, 17 June 1895, 7.

381891 England \& Wales Census, Liverpool, Bootle-Cum-Linacre, Lancashire, England, digital image s.v.

"Hulan Jane Matthew", Ancestry.com. Accessed 14 October 2020.

39 "Ladies at Football", Windsor and Eton Express, 7 December 1895, 3.

401891 England \& Wales Census, East and West Thirston, Morpeth, Northumberland, England, digital image s.v. "Ellen Hudson", Ancestry.com. Accessed 14 October 2020.
} 
London's Hainault Street, where her father William Fenn was the pub landlord. ${ }^{41}$ Oliphant married Alfred Hewitt Smith in December 1895, in the process perhaps, making a slight step up the social ladder. ${ }^{42}$ Emma and Florence Clarke half-sisters from Plumstead, were more in keeping with the club's desired image. ${ }^{43}$

A team photograph taken in Newcastle suggests that Emma Clarke had a mixed race background and she was recently presented as the first recorded Black woman footballer. This claim has yet to be substantiated more conclusively by further evidence, but has led to a good deal of debate on the issue. Some commentators such as Jean Williams, have gone so far as to describe the assertion as a sporting myth. ${ }^{44}$ There is little evidence in the official records to support Emma Clarke's ethnic heritage. In 2019, however, Dave Witham, a descendant of Emma's half-sister, Florence Clarke, recalled that his late grandmother told him of an affair in the family's past which resulted in a mixed race child. ${ }^{45}$ Later match reports described Emma Clarke as a 'dark girl, of short stature, but sturdy and so fleet of foot' ${ }^{46}$ A local report for a match in Stirling in 1896, refered to her as 'a Coloured Lady of Dutch build' ${ }^{47}$ These references and other photographic evidence presents a good case in favour of Emma's ethic background, but the COVID-19 pandemic has frustratingly halted further research. Controversy also surrounded a young player named Daisy Allen. Nicknamed 'Tommy', the level of skill displayed by this player led many to think she was actually a boy. The Northern Whig, however, noted that another player, Nellie Gilbert was the mother of 'Tommy'. Nellie Gilbert was the maiden name of Ellen Richardson, and her eight-year-old daughter Edith Richardson was most likely to have been the player known as 'Tommy'. ${ }^{48}$

\section{The first British Ladies Match in Belfast}

The appearance of women's football in later decades of the ninteenth century was sometimes associated with the progress of women's rights, and in particular voting rights. The first votes for women came with the introduction in England and Wales of the Municipal Franchise Act in 1869. In Ireland moves to introduce local reform often played second fiddle to the campaign to introduce Home Rule. When the bill failed in 1886 the impetus for local reform across Ireland also waned. ${ }^{49}$ Attempts at local reform such as the Municipal Corporations Act (Ireland) of 1887 was largely confined to Belfast, though amendment 10 did include women in the franchise. ${ }^{50}$ The franchise element of the Londonderry Improvement Bill of 1896, however, did not extend to women. ${ }^{51}$ Isabella Tod was quick to take issue with this admission in a letter of June 1896:

\footnotetext{
${ }^{41} 1871$ England \& Wales Census, Romford, Ilford, Essex, England, digital image s.v. "Florence Beatrice Fenn", Ancestry.com. Accessed 14 October 2020.

42 “England \& Wales, civil Marriage Index, 1837 -1915,” Edmonton, Middlesex, (Ref: Oct, Nov, Dec, 1896) digital image s.v. “Alfred Hewitt Smith”, Ancestry.com. Accessed 14 October 2020.

431891 England \& Wales Census, Plumstead, Kent, London, digital image s.v. "Emma Clarke", Ancestry.com. Accessed 14 October 2020.

${ }^{44}$ Jean Williams, "Emma Clarke (born 1871) was a lost Lioness", JJ Heritage, 8 April 2020, http://www.jjheritage.com/blog/emma-clarke-born-1871-was-a-lost-lioness-a-pioneering-victorian-footballplayer-but-much-remains-to-be-known-about-her-life.html Accessed 28 October 2020.

${ }^{45}$ Andy Mitchell, "A Case of Mistaken Identity - Emma Clarke and the British Ladies Football Club", Scottish Sports History, September 24, 2019, http://www.scottishsportshistory.com/sports-history-news-and-blog/a-caseof-mistaken-identity-emma-clarke-and-the-british-ladies-football-club.html Accessed 25 September 2020.

46 "Palace Aux Dames, Women Footballers in Cardiff", South Wales Daily News, 4 November 1895, 7.

47 "Female Footballers in Stirling”, Stirling Sentinel, 30 June 1896, 3.

481891 England \& Wales Census, Hackney, London, England, digital image s.v. "Ellen Richardson", Ancestry.com. Accessed 14 October 2020.

${ }^{49}$ Marie Coleman, “The Irish Revolution 1916 - 1923”, Routledge, 2014, 60, 61.

50 “The Belfast Municipal Franchise Bill”, Belfast Newsletter, 11 July 1887, 8.

51 “Derry Corporation Bill”, Derry Journal, 3 July 1896, 7.
} 
Since 1869 every borough in England and Wales has it, since 1882 every town Scotland has it, since 1887 Belfast has it, and within the last year or two Kingstown has it. The truth is it is Derry that is being left behind in the march of justice and common sense. ${ }^{52}$

It was the Manchester MP Jacob Bright, a contemporary of social reformer John Stuart Mill that introduced the women's voting rights to the Municipal Franchise Act of $1869 .{ }^{53}$ Glasgow MP Charles Cameron brought forward his Amendment Act extending the measure to Scotland in the spring of $1881 .^{54}$ The 1881 amendment's entry onto the Parliamentary agenda coincided with the first matches of the Lady Players in Edinburgh and Glasgow and some commentators have linked the two events going as far as saying that the matches helped deliver votes for women. ${ }^{55}$ This is a gross exaggeration; as there is little evidence that the players were politically active. Gordon and Scholes had stated that they had formed the 'association for the purpose of popularising football as a feminine pastime', but this popularisation was more aimed at attracting an audience than at upholding any kind of manifesto. ${ }^{56}$ The British Ladies also referenced the political environment of the 1890s through the club's figureheads Nettie Honeyball and "Mrs Graham". The primary motive however was to attract sponsorship and gain the sort of public and press coverage that the accepted women's sports like tennis and hockey, were receiving.

Much of the early development in Irish soccer centred on Belfast and the North East. The Irish Football Association (IFA) was formed in 1880 to govern the game in Ireland. Bloomfield Park in Belfast was chosen to host the first international against England held on 18 February $1882 .{ }^{57}$ It took slightly longer for the game to take hold in Dublin. Students from Trinity College, Dublin, founded the Dublin Association Football Club followed soon after by Dublin University AFC. The sides played their debut on 7 November 1883. The IFA in Belfast administered football across the Island but a two tier system soon developed between the North and South, which was accentuated further by the formation of the Leinster Association in 1892. ${ }^{58}$ As much of the infrastructure for the association game was based in Belfast, it was the obvious location for the British Ladies Club to stage their Irish debut.

On 18 June 1895, what has now been recognised as the first women's association match in Ireland took place at the Cliftonville enclosure. The event attracted 6,000 spectators, at the time it was a record attendance figure for the ground. One draw may have been the possible attendance of Florence Dixie. Lady Florence however was not present, crippled by arthritis; she was residing at Glen Stuart. She travelled there a few weeks before the British Ladies London debut and there is no evidence that she attended other matches during the tour. ${ }^{59}$ The players were driven from their hotel, the Shaftesbury, and were greeted by crowds that lined the streets with great enthusiasm. By the time they made it to the ground the announced kick off time of 7:30 was long passed, but they were still cheered onto the field. It was noted that the entourage totalled 24 persons, with a Miss Peterson and Miss Lovelle listed as reserves, yet each side only contained nine players. This discrepancy in numbers was a common feature in

\footnotetext{
52 "Municipal Franchise for Women", Derry Journal, 17 June 1896, 3.

${ }^{53}$ Dr Kathryn Rix, "Women and the Municipal Franchise," The History of Parliament, August 2 2019, https://thehistoryofparliament.wordpress.com/2019/08/02/women-and-the-municipal-franchise/. Accessed 22 October 2020.

54 “Female Municipal Franchise Bill”, North British Daily Mail, 18 May 1881, 4.

55 "Secret history of women's football reveals how riots during Auld Enemy clash led to Scotland banning the developing game", Daily Record, 1 September 2013, https://www.dailyrecord.co.uk/news/real-life/secrethistory-womens-football-uncovered-2243257 Accessed 3 May 2021.

56 "The Ladies Football Match in Edinburgh", Scotsman, 9 May 1881, 6.

57 "Northern Ireland boasting rich history", Inside UEFA, 18 February 2020,

https://www.uefa.com/insideuefa/member-associations/nir/. Accessed 28 October 2020.

58 "Association Football, Its Rise and Progress in Dublin", Dublin Evening Telegraph, 4 March 1893, 7.

59 “The Marquis of Queensberry”, Dundee Evening Telegraph, 9 April 1895, 2.
} 
British Ladies matches-indeed the club's debut at Crouch-end was one of the few occasions where they fielded eleven-a-side. The teams lined up as follows:

Blues - Mrs Graham (Helen Matthew), Emma Clarke, Hannah Oliphant, Susie Earle, Susie Yates, Miss Wolburn, Miss Bird, Lizzy Yates, Florence Clarke.

Reds - Lily Lynn, Miss Vernon, Nellie Clarke, Phoebe Smith, May Hudson, Ruth Coupland (Ellen Dunn), Miss Edwards, Nellie Gilbert (Ellen Richardson), Daisy Allen (Edith Richardson). ${ }^{60}$

The Reds won the toss and kicked off. Reports of the game noted that there was a lack of combination play with the match paced at a rather low tempo. The crowd were, however, immediately captivated by the play of Edith Richardson 'Tommy'. She scored in the first half despite Helen Matthew's protests for off-side but Matthew's efforts in the second period ensured that the score remained 1-0. On the final whistle many of the spectators rushed out of the ground to witness the team's departure and as they progressed, the player's carriage was followed by a crowd of almost two thousand enthusiastic people. In response to their cheering, the players waived their hats and handkerchiefs.

On the Antrim Road the horses were removed from the carriage and the job of transporting the players was taken up by members of the crowd of enthusiasts. The streets leading to the hotel were lined on each side. At the Shaftsbury hotel, Alfred Hewitt Smith addressed the crowd stating that Belfast had given the players the best reception they had had up until that point. The captain Helen Matthew, called for 'three hearty cheers for the City of Belfast'. The Social Review painted a rather negative view of the proceedings, describing the player's costumes as the acme of ugliness and the majority of the spectators as being of a very low class. This copy was in marked contrast to the coverage of the concluding matches of the Irish Ladies Hockey Union:

The final match of the competition was played on Saturday morning at Donnybrook, between Alexandra College $2^{\text {nd }}$ XI, and Beechfield Ladies' XI. A fast game resulted in a victory for the College XI, by two goals to one. The goals for the College were shot by Miss L. Jones and Miss E. Jones respectively. The combination and passing of the College forwards was very good. The back play of Miss T. Henshaw was admirable, and among the forwards Miss M. Faussett and Miss L. Jones deserve special praise. ${ }^{61}$.

The Northern Whig put a better spin on their account of proceedings but they did note that the attendees were not an ordinary football crowd, adding:

One scanned the faces around to recognise not the present football crank or even the past enthusiast, but the grave medical man, the city magistrate, and the public official (with their wives and daughters, and sisters, cousins and aunts), making a thick sprinkling amidst the rank and file of spruce citizen, washed artisan, and smug apprentice. ${ }^{62}$

\section{The British Ladies visit Dublin and play the North End Juniors}

The Belfast Newsletter announced that the British Ladies had traveled to Dublin on 20 June 1895. Few details of the trip were divulged except to say the visit was less successful than their appearance in Belfast. It is possible that the sides had stumbled into another political debate surrounding education. Alice Oldham secretary of the association of Irish School Mistresses, was at the head of a campaign to increase the opportunities for women in further education and in particular entry for women to Trinity College, Dublin. In June 1892 a petition containing 10,000 signatures calling for the admittance of female students was delivered to the college. After almost three years of intransigence from the institution a press campaign was initiated to

\footnotetext{
60 "The Lady Footballers in Belfast, The Match at Cliftonville", Belfast Newsletter, 20 June 1895, 3.

61 "Society in Town And Country", The Social Review, 6 April 1895, 4.

62 "The Lady Footballers in Belfast - A Novel Spectacle", Northern Whig, 20 June 1895, 8.
} 
pressure the College into action. This however, had the effect of hardening attitudes, and on 10 May 1895, Trinity announced that it would not be accepting female students. ${ }^{63}$ As much of the South's association football activity centred on Trinity College it may have been considered inappropriate to welcome female footballers onto college grounds so soon after barring female students.

The British Ladies were back in Belfast on Saturday 22 June 1895 where they met a local male select at the Cliftonville ground. The match attracted 3,000 spectators, half the number that attended the opening match, with the conditions considered overly warm for football but the players preserved with a short demonstration match. ${ }^{64}$ The Reds had most of this game until the Blues, following a corner, broke out for a counter attack which resulted in the only goal. The main event between the women and North End Juniors was marked by the poor finishing of the North End side and excellent goal keeping of Helen Matthew. The North End had the bulk of the match but only had two goals to show for their efforts, scored within the first few minutes of the kick-off. In the second of the fifteen minute halves the British Ladies came into their own. Towards the end of the match they laid siege to the North End goal which resulted in two goals being scored to equalise the match. The last goal of the day was marked down to a goal-keeping error, but the crowd seemed satisfied by the result. ${ }^{65}$ At the conclusion of the football match, a short athletics event was held. This involved a 120 yard race for the women and 220 yard handicapped race for the North End players. Florence Clarke won the women's race with Hudson second and Edith Richardson third. There was also a place kick contest which saw the players of both sides compete. Despite the reduced crowd overall, the first visit of women footballers to Ireland was considered a success. ${ }^{66}$

\section{The Return}

The British Ladies Football Club returned to Ireland in the spring of 1896. The proposed tour was announced to commence at City and Suburban Grounds on 16 May 1896. The opening fixture was cancelled due to a missed ferry connection, and following a desperate wire by Alfred Hewitt Smith to the offices of the Evening Herald, an alternative date of 18 May 1896 was arranged. ${ }^{67}$ The match was billed in most papers and advertisements as Ireland \& Scotland $v$. England. Such a title was justified by the inclusion of two players: Miss A. Baldwin and Violet Clarence. Miss Baldwin may have been a player with a rival side to the British Ladies which formed during the spring of $1895 .{ }^{6}$ Organised by a Miss Milford, they made appearances in Bolton, Manchester and Blackpool. The attendances for the Blackpool fixtures were poor, but the side seems to have folded after a disastrous match in Lancaster which ended in a pitch invasion. Many of the players including Miss Baldwin drifted over to the British Ladies as they commenced their autumn season.

In contrast to prominent competitors such as Helena Bertha, Grace Rice and May Langrishe, little information was given about Miss Baldwin. Indeed, the only clue to her background was a vague description of her in the press as a 'vivacious young Irishwoman'. She was listed in the team line up for a match in Nottingham during December 1895 as 'A. Baldwin', and a search through census records has produced a possible candidate, Annie Amelia Baldwin. The daughter of brick layer and builder Henry Richards, Annie was born in

\footnotetext{
${ }^{63}$ Susan M. Parks, "Alice Oldham and the admission of women to Trinity College, 1892-1904", Trinity Morning Discourse, 10 May 2004. http://www.tcd.ie/Secretary/FellowsScholars/discourses/discourses/2004_S\%20Parks\%20on\%20A\%200ldham. pdf.html Accessed 2 October 2020.

64 "The Lady Footballers", Northern Whig, 22 June 1895, 7.

65 "The Lady Footballers", Northern Whig, 24 June 24 1895, 7.

66 "Ladies Football Team v North-End Juniors", Belfast Newsletter, 24 June 1895, 3.

67 "Postponed, Lady Footballers Miss the Boat and Won't Play To-day", Evening Herald, 16 May 1896, 5.

68 "Five Minute Chat by Willow the Wisp - The Lady Footballers", Blackpool Times, 12 June 1895, 6.
} 
1874 in Fethard, County Tipperary, presumably while he was in Ireland on a construction project. Annie was brought up in London, and the 1891 census lists her as living in London at 116 Blackwell Lane, married to Alfred Baldwin, a GPO worker. ${ }^{69}$ It can not be said for certain that this is the player, but she does at least merit further investigation.

Violet Clarence was the stage name for Georgina Brewster, but it is unclear what name she used for her football appearances. Georgina was born in the Fife town of Burntisland and lived in Edinburgh during the late 1880s. By 1893, she was making her first tentative steps towards her stage career. ${ }^{70}$ During the autumn of 1894 and early 1895 , she was making sporadic stage appearances. The naming of the sides helped generate interest, with a good attendance at the Jones's Road ground. The players posed for photographs before play commenced and resulting reports noted that the large turn-out were satisfied with the 3-2 win for the Scotland $\&$ Ireland side. ${ }^{71}$

\section{Debating the 'New Women'}

The player's arrival sparked debate within the local press. In its introduction to a report on the sides Dublin debut the Evening Herald of 19 May 1896 commenting to the effect that of the likely new roles that may develop for women, not even the most fervent advocate would conceive of their stretching to football. The Social Review of 23 May 1896 reiterated its damming commentary from the previous year, casting doubt on whether these matches could be an entertainment that respectable women could appreciate. The Social Reveiw, also portraied the attending crowd in a rather poor light as, the following paragraph illustrates:

I believe some of the players at Belfast last year were frightened nearly into hysterics by the language addressed to them - not in a friendly way - by some of the crowd, and it is certainly a fact that after the match, the spectators treated them so rudely as to make the personal protection of a policeman to each member of the team an absolute necessity. ${ }^{72}$

This description is at odds with the Belfast Newsletter account; it seems the prejudice of the Social Review was such that they were prepared to distort the events at Belfast, to push their own narrative. Elsewhere, a debate of sorts on the role of women in sports and in general life was taking place. The Reverent M.F. Bovenizer gave a lecture at the Thomas Street Schoolroom in Enniskillen on the subject of 'The New Women'. The recently popularised term was used to describe progressive females of the era. It came from the article The New Aspects of the Woman Question (1894) by the Irish born novelist Sarah Grand (Frances Elizabeth Bellenden Clarke). The title was borrowed and shortened to 'New Women' by another author, Ouida (Marie Louise Rame) and quickly caught on. ${ }^{73}$ The Reverent Bovenizer's lecture was covered by the Portadown News, and he immediately honed in on the catch-all nature of the phrase and how the people associated with it had been caricatured and misrepresented in periodicals and books. Reverent Bovenizer states that women should pursue whatever activities might interest them, but he does draw a slightly blurred line at football:

Nobody has the right to define a women's place except herself. Should she ride a bicycle? Yes if she likes said Mr Bovenizer. She has as good a right to ride a bicycle as a man has. Should she play football? Fundamentally she has as good a right to play football as a man has, but he wasn't advising her to do it. ${ }^{74}$

\footnotetext{
691911 England \& Wales Census, West Hackney, London, England, digital image s.v. "Annie A Baldwin”, Ancestry.com. Accessed 14 October 2020.

701891 Scotland Census, St Cuthberts, Edinburgh,Scotland, digital image s.v. "Georgina V. Brewster", Ancestry.com. Accessed 14 October 2020.

71 “The Lady Footballers an Interesting Display”, Evening Herald, 19 May 1896, 3.

72 “The British Ladies Club", The Social Review, 23 May 1896, 5.

${ }^{73}$ Marlyn Bonnel, "Sarah Grant and the Critical Establishment: Art for [Wo]man's Sake", Tulsa Studies in

Women's Literature, 14 (Spring 1995) 123.

74 “The New Women", Portadown News, 16 May 1896, 8.
} 
The reaction to women's football in Ireland seemed to echo the political and cultural divide within the country the agrarian South, in divergence with the more industrial North. A few days after the second 'international', a grander match was arranged four days later between a select side from the British Ladies squad and a Dublin Gentlemen's XI. The Dublin men, were reported to have fielded an Ireland Internationalist but did not reveal his identity. Another large crowd came to the Jones's Road Ground to see the men lose 5-2 (The Belfast Newsletter recorded the score as 7-2). The Evening Herald's account of the British Ladies side described their play as an 'agreeable surprise" ${ }^{75}$ From Dublin the sides headed north to Drogheda, arriving to find lodgings in town on Monday 25 May 1896. They had hoped to play at the local Athletics Ground but were refused permission and so had to make do with the Shamrock Lodge, a field on the outskirts of town. The Scotland \& Ireland $v$. England format from the opening matches returned for this fixture with the Scotland \& Ireland side recording a 2-0 win. A few days later the select side was in Derry, where they met another male side, St Columb's Court Rangers. This ended in a 5-5 draw. ${ }^{76}$

\section{Florence Dixie's withdrawal and the collapse of Mrs Graham's XI}

From the autumn of 1895 the British Ladies ran a second eleven drawing on players from the collapsed side run by 'Miss Milford'. In the spring of 1896 the sides diverged with one fronted by Helen Matthew (Mrs Graham) heading to Scotland for a two month tour. In publicity, it was stated that Mrs Graham's XI had no connection to the British Ladies Football Club, but this is unlikely. This squad contained not only Ellen and 'Tommy'(Edith Richardson: in Scotland, Edith played under the name 'Miss Brown'), but also Emma Clarke. ${ }^{77}$ Her half sister, Florence, remained with the main squad and, it seems, the divergence of the Originals and the British Ladies Football Club was more for commercial reasons than any personal fallout. 'Mrs Graham's Original Lady Footballers' made a successful start to their Scottish tour with a 5-5 draw against a Partick male select, included in the Belfast Newsletter's round up of 'Leading Scotch Matches' on 18 May 1896. As the Scottish tour progressed, the mood turned sour. The Evening Telegraph of 25 May 1896 covered the crowd trouble that took place during a match between Mrs Graham's XI and a local select of Irvine Juniors. A more serious disturbance took place at Saracens Park in the north of Glasgow were the players and spectators were ambushed by an angry mob. The Wexford People reflected on the event in relation to the perceived image of Irish society as easily agitated and politically volatile:

The police charged the mob with their truncheons, and in the melee several persons received injuries from stones and other missiles. A policeman got a nasty blow on the head. If this occurred in Ireland what an outcry there would be with regard to savagery of the "dirty Irish."

The main British Ladies side didn't experience this kind of response in Ireland, but there was disquiet surrounding the team. Rumours circulated from early May 1895 that some players were involved with the theatre. After the club's Scottish debut, the Paisley Express noted that six of the squad members had appeared in pantomime, with one player, Lena Horwood, involved with the Paisley Theatre manager, Eade Montefiore's production of Babes in the Wood. ${ }^{79}$ For the match played in Wexford on 23 June 1896, the local paper noted that most of the women players were music hall artists. ${ }^{80}$ During the early to middle part of the century, theatre performers were not held in high regard, but by about 1870, actors and other artists were considered more respectable, although such endeavours were rarely encouraged. ${ }^{81}$

\footnotetext{
75 “The Lady Footballers Defeat a Team of Gentlemen", Evening Herald, 25 May 1896, 4

76 "The Lady Footballers in Drogheda", Irish Independent, 30 May 1896, 6.

77 “The Lady Footballers at Skelmorlie”, Largs \& Millport Weekly News, 23 May 1896, 4.

78 "Lady Footballers Mobbed", Wexford People, 3 June 1896, 8.

79 “The Lady Footballers, The Drawings", Paisley Daily Express, 6 May 1895, 3.

80 "The Lady Footballers, The match at Wexford Park on Monday", Wexford People, 24 June 1896, 5.

${ }^{81}$ Michael Baker, "Rise of the Victorian Actor", Routledge, 2016, 21.
} 
Performers such as Ellen Dunn may have still been amateur at this point, but for figures like Lady Florence, to have engaged in theatricals at even an early stage in their career would have been too much. This also massively contradicted the claims that club membership drew exclusively on the upper-middle class. Lady Florence finally felt that she had been sold this project under false pretences, but her exit from the British Ladies was handled with tact avoiding embarrassing and possibly damaging publicity. The British Ladies Club continued listing Lady Florence Dixie as president in club promotions. It was during the second tour of Ireland that matters came to a head, with an angry letter penned by Lady Florence to the Irish press. This appeared in most titles on 12 June 1896:

Having been presented to me that, various teams are travelling about Ireland and elsewhere representing that I am president of their club. I would be obliged if you give a prominent denial to said statement. I am president of no football club. ${ }^{82}$

The move it seemed, was calculated to stop the club from using Lady Dixie's name while at the same time avoiding another press 'sensation'. The tactic worked, to an extent most of the commentary was limited to Ireland, with the San Francisco Call and the New Zealand Graphic being the only papers outside Ireland to approach the subject. ${ }^{83}$ Florence Dixie was subsequently removed from British Ladies advertisements, although they later found a form of wording which allowed them to continue using her name.

\section{Wexford and the last hoorah}

The Irish tour continued with a ferry trip to Moville aboard "Jeanie Deans" for an Ireland $v$. England match. With 'Tommy' in Scotland with Mrs Graham's XI, May Hudson became a substitute 'Tommy' for main side. A fixture at Strabane saw the Ladies win 3-2 against a local men's side, which attracted another large crowd. Also attracted were thieves, who got into the gentlemen's dressing room and made off with several items of value including a watch and chain. ${ }^{84}$ A fixture was arranged for Wexford where the ladies were set to take on the St Patrick's Club. St Patrick's, proficient at Gaelic Football, spent several days training to association rules ahead of the match which took place at Wexford Park on 22 June and resulted in a 3-3 draw. ${ }^{85}$

The British Ladies farewell to the Island was marked with a concert at Wexford Theatre Royal by the club's theatrical contingent. This would almost certainly have included Ellen Dunn and Georgina Brewster. ${ }^{86}$ After Mrs Graham's Original Lady Footballers had folded many of the players returned to the main British Ladies side. During the summer and early autumn of 1896, the British Ladies Club played numerous matches in Wales and the West Country. ${ }^{87}$ Georgina Brewster continued with the club, and also made appearances alongside Ellen Dunn during the British Ladies post match events. She dropped out of the club during 1898 pursue a stage carrier as Violet Clarence. ${ }^{88}$ Ellen Dunn left the club in autumn of 1897 to pursue a successful professional career as Lily Flexmore, an act which was developed during her time with the British Ladies Club. ${ }^{89}$

\footnotetext{
82 "To the Editor of the Freeman", Freeman's Journal, 12 June 1896, 12.

83 "In the Smoke Room", The New Zealand Graphic and Ladies Journal, 19 September 1896, XVII, no. 12, 359.

84 "Alleged Larceny at a Football Match at Strabane", Belfast Newsletter, June 5, 1896, 7

85 "The Lady Footballers - The Match at Wexford Park on Monday", Wexford People, 24 June 1896, 5.

86 "Lady Footballers - Booked for Wexford", Wexford People, 10 June 1896, 8.

87 "Ladies Football at Carnarvon", Liverpool Echo, 11 July 1896, 3

${ }^{88}$ An account of a post-match stage performance at the Victoria Hall, Southend, appeared in the Barking, East Ham \& Ilford Advertiser, 17 April 1897 (4) Georgina Brewster and Ellen Dunn were featured among the British Ladies Football Club members that performed in the concert. Also taking part was Phoebe Smith, captain and later club secretary.

89 “Le Zephyr for New York Theatre", New York Tribune, 9 December 1907, 7.
} 
The club's first sponsor, Florence Dixie, spent the last decade of her life suffering from arthritis, and died in 1905 after contracting diphtheria. ${ }^{90}$ She was still politically active during those last years, campaigning for women's voting and marriage rights, things that are pretty much taken for granted today. Her early death may have led to her being excluded from the pantheon of female reformers, and it would probably be irksome for her, that of her work and achievements, her brief period of presidency of the British Ladies Club is what Florence Dixie is most remembered for today. The British Ladies Club's proposed tour of the South East prompted the Kent Football Association's (FA) secretary, J. Albert, to put forward a motion to the FA Council on 25 August 1902, prohibiting players from affiliated clubs to compete against women's teams. ${ }^{91}$ This had little effect on the British Ladies and in publicity for a match in April of 1903 against a male side, the Wesley Club in Biggleswade, the reception received in Belfast in 1895 was listed among the clubs successes. ${ }^{92}$ By 1907, British Ladies Club had fizzled out and many of the figures connected to it had faded from the scene. Alfred Hewitt Smith died suddenly in the early spring of 1918 his wife Hannah Oliphant returned to the North east and died in Durham in $1923 .{ }^{93}$ Jessie Allen Smith, a former club secretary, never remarried after the death of Frederick Smith and died in 1922 at the University College Hospital at Leigh on Sea. ${ }^{94}$

Helen Matthew lost interest in football after the collapse of the Originals, but in 1900 she was involved in a court case over unpaid football shirts. She appeared before the magistrate under a false name, Helen Graham Matthews, but by cross referencing her address given on court reports with the 1901 census, her true identity, Helen Matthew, can be revealed. ${ }^{95}$ Until every recently, Helen Graham Matthews is the name she has been associated with. She has also been linked to the 1881 tour as an organiser (despite 'Mrs Graham' not appearing on any of the Lady Players team sheets) and as a suffrage campaigner with some sources listing her as a prominent Scottish Suffragette. ${ }^{96}$ Nettie Honeyball has also been described as a suffragette, but there is no real evidence of these players being politically active. An error made by researchers has been to take many of the interviews and press copy at face value. Richard Saunders in his book Beastly Fury, comments of both the British Ladies and 1881 tours that 'the background of these Glasgow women is not known but, as with Nettie Honeyball's team, it's likely they were from the respectable classes. ${ }^{97}$

There has been a tendency to employ the model used to explain women's sport as a whole in the nineteenth century to describe the development of women's football in particular. ${ }^{98}$ The result has been a range of curious anomalies. Women's football has a different point of origin from the excepted women's sports of the period. The participants differed in background and an examination of the backgrounds of the British Ladies squad reveals that many came from working class backgrounds, with some connections to the theatre. This was a world away from the more affluent participants in croquet, tennis or cricket. Women's football

\footnotetext{
90 “The Death of Lady Florence Dixie," Windsor \& Eton Express, November 11, 1905, 6.

91 "The Football Association, Division 10", Sporting Life, August 26, 1902, 4.

92 "Ladies v Gentlemen, A Surprise for Biggleswade", Biggleswade Chronicle, 1 May 1903, 3.

93 “England \& Wales Death Registration Index, 1916-2007”, Auckland, Durham, (Ref: Jan, Feb, Mar 1923), digital image, s.v. "Hannah Smith", Ancestry.com.

94 Partick Brennan, "Nettie Honeyball", Donmouth, 2014.

http://donmouth.co.uk/womens football/nettie honeyball,hyml. Accessed 28 September 2020.

${ }_{95}$ A report on the trial in the Northern Daily Telegraph, 5 April 1900 (3) lists 'Helen Graham Matthew's' address as 10 Worchester Drive North. When cross-referenced with the 1901 census the residents listed are Helen Matthew and her Aunt Jane Hayne. 1901 England \& Wales Census, West Derby, Lancashire, digital image, s.v. "Helen Matthew", Ancestry.com.

96 “Mrs Graham: Promoting the Women's Game", Football Makes History, 5 June 2020.

http://footballmakeshistory.eu/mrs-graham-promoting-the-womens-game/. Accessed 28 September 2020.

${ }^{97}$ Richard Saunders, Beastly Fury, The Strange Birth of British Football, Bantam Books, 2010, 202, 204.

${ }^{98}$ James F. Lee, The Lady Footballers, Struggling to Play in Victorian Britain, Routledge, 2007, 12.
} 
needs to be studied on its own terms rather than as an offshoot of nineteenth century women's sporting activity. In this way a better understanding of the subject may be reached.

\section{Aftermath of the British Ladies tour and how women's football progressed}

During the later half of the nineteenth century and the first decades of the twentieth, an activities programme was instigated for industrial workers. Many firms organised social events and activities such as company dances, camera clubs, theatre groups and gardening. Sports also played a large part, with many of the recognised women's sports like hockey included in the recreational programme. ${ }^{99}$ With the outbreak of World War I more women entered the workplace, with some employed in support industries but mainly in the munitions factories. In Ireland, existing works in Belfast such as James Mackie \& Sons were converted to munitions production. Five purpose-built centres were constructed in the south, at Waterford and the shell and fuse factories at Parkgate Street in Dublin. ${ }^{100}$

The new centres for arms production replicated many of the sports and social programmes that were commonplace in peacetime industry. Soccer activity, however, was confined to Belfast and the surrounding area. Diana Scott, wife of the Distillery Football Club secretary Walter Scott, played a large role in organising women's teams with fundrasing matches for war charities. ${ }^{101}$ On Boxing Day 1917 an Ireland $v$. England match was staged at Grosvenor Park in Belfast with the Ireland side containing local women. David Brooks, a Belfast man working in the North east of England, managed the visiting side. Brooks, once a player with the Distillery Club, had maintained connections with Mrs Scott, and the idea of a representative match was soon presented to the Munitions Cup Committee back in Tyneside. ${ }^{102}$ On the day, about 20,000 spectators were in the ground. A return fixture was played the following autumn on 21 September $1918 .{ }^{103}$

Diana and Walter Scott remained active during the immediate period after WWI and helped bring the Dick Kerr and the French Select sides to Belfast in 1925, but a proposed match in Dublin was halted by the Football Association of Ireland (FAI). ${ }^{104}$ The political divide which had been apparent during the British Ladies tour was now firmly entrenched, with the IFA continuing in the Home International Championships and FAI in the Free State struggling to find recognition from the British Associations and FIFA. ${ }^{105}$ The Football Association imposed an embargo on affiliated clubs hosting women's matches in 1921 the Scottish Football Association (SFA) would not follow suit until 1947. In Ireland women's football sat outside the political divide, and the game received a boost with the arrival of Rutherglen and Edinburgh Ladies in 1927. The sides even ventured south, where Rutherglen took on a team of local women at Milltown. ${ }^{106}$

The introduction of the Irish Constitution in 1937 also played a part in limiting women's participation in sport. Article 41.2 stated that:

\footnotetext{
${ }^{99}$ Steven Lea Crewe, "Sport, Recreation and the Workplace in England, c. 1918 - c. 1970" (PhD diss De Montford University, July 2014).

${ }^{100}$ Fionnuala Walsh, "We work with shells all day and night : Irish female munitions workers during the First World War”, Saothar Journal of the Irish Labour History Society, 42 (2017), 2, 3. http://hdl.handle.net/10197/10075. Accessed 8 October 2020.

${ }^{101}$ Alexander Jackson, "The Pioneer of Ladies Football in Ireland: A Brief History of Mrs Scott”, Playing Pasts, March 29, 2021. https://www.playingpasts.co.uk/articles/football/the-pioneer-of-ladies-football-in-irelandabrief-history-of-Mrs-Scottpart-on/. Accessed 30 March 2021.

102 "Former Wallsend FC Manager Dies", Sheilds Daily News, 25 October 1947, 7.

103 'Partick Brennan, The Munitionettes, (Rowlands Gill: Donmouth Publishing, 2007) 29.

104 “Ban on Lady Footballers, French XI, Cannot Play in Dublin", Northern Whig, 1 June 1925, 3.

105 Cormac Moore, “The Irish Soccer Split”, History Ireland, 23, no.6 (November December 2015 https://www.historyireland.com/20th-century-contemporary-history/the-irish-soccer-split/.) Accessed 6 October 2020 .

106 “Rutherglen Ladies win in Ireland”, Daily Record, 27 August 1927, 16.
} 
By her life within the home, woman gives to the State a support without which common good cannot be achieved. ${ }^{107}$

Earlier legislation, the 1935 Conditions of Employment Act, had enabled the Minister of Works to either prohibit or to limit the number of women working in industry. The Act also ensured that women could not outnumber men in a particular work setting. ${ }^{108}$ During the 1930 s, there was a stance against foreign cultural influences and football was one of the sports considered non-Irish. In 1934, for instance, the Camogie Congress passed a motion banning Camogie players from participation in 'foreign games' 109 No such restrictions existed in Northern Ireland, and the industries around Belfast produced a string of women's soccer sides by the late 1920s, from works such as the York Street and Milewater Mills, the East Belfast Ropeworks and the Owen O'Cork works. One of the standout players of the Rutherglen/Edinburgh tours, Molly Seaton played a prominent part in these matches especially during the 1932 Irish Cup final where Seaton's XI beat the Ropeworks at Grosvenor Park. ${ }^{110}$ Internationals featuring a proper Irish representative side were also played during the 1930s to good attendances, the most notable being the Ireland $v$. France match at Grosvenor Park in 1932. ${ }^{111}$ The Ulster factory sides enjoyed a revival post WW2 with, among others, the Portadown side, which featured workers from the shadow plant of the Barrhead firm, Robert Wilson \& Son. The side travelled to the South of Scotland in 1950 to play matches in Dumfries and Annan. ${ }^{112}$ The Portadown works also provided players for the Ireland side that took on Preston Ladies at Windsor Park ${ }^{113}$ Industry had provided women's football with the ideal environment it needed to develop and factory sides continued to be produced into the $1960 \mathrm{~s}$.

\section{Conclusion}

The response to women's football, when it arrived in Ireland, was relatively mixed. A good deal of scepticism and some out-and-out hostility can be detected in contemporary press reports; however, there is evidence that some form of debate was taking place. Large crowds were attracted to the matches. In some instances, such as the debut fixture in Belfast this could be seen as positive. Contemporary research has often focused on the negative aspects of press coverage and on the social disturbances which marred some fixtures. In the case of the British Ladies Club, such disturbances certainly attracted a good deal of criticism, but the press of the period also helped promote the club and in the process the game in general. The popular press also propagated the club's desired image of middle-class respectability. The true backgrounds of the players, and in some cases their connections to the theatre, were left to the margins so that even unpleasant press commentary was nowhere near as damaging as it could have been.

The development of women's association football can be characterised as series of peaks and trougths, with periods of intense activity followed by gaps. Progress in Ireland also reflected this model to some extent. Political and religious dynamics, however, complicates the issue further, for the North of the country saw a greater acceptance of the female players, especially during World War I. In the south, religious conservatism in the 1930s led to the game being shunned, and it is not until the 1950s and 1960s that it makes a tentative return. In

\footnotetext{
${ }^{107}$ Caitriona Beaumont, "Reference to women's place in home must be removed from Constitution," The Irish Times, 4 October 2018, http://www.irishtimes.com/opinion/reference-to-woman-s-place-in-home-must-beremoved-from-constitution-1.3650608. Accessed 6 October 2020.

${ }_{108}$ Mary McAuliffe, "The Irish Woman Worker and the Conditions of Employment Act, 1936," in "Women: Special Issue” ed. Mary Clancy and John Cunningham, Saothar 36 (2011): 37. http://www.jstor.org/stable/23200046. Accessed 22 October 2020.

${ }^{109}$ Ríona Nic Congáil, "'Looking on for Centuries from the Sideline': Gaelic Feminism and the Rise of Camogie." Éire-Ireland 48, no 1 \& 2 (Spring/Summer 2013): 187, 188.

110 “Molly Seaton's XI Win Cup", Northern Whig, 20 August 1932, 3.

111 "Ladies Football”, Northern Whig, 5 August 1932, 12.

112 "Irish Lady Footballer's Visit", Dumfries Standard, 5 July 1950, 3.

113 "Women Football Players", Belfast Newsletter, 18 July 1950, 6.
} 
this chronology of events the visits of the British Ladies Club in 1895-96 is important not only for presenting the first women's matches in Ireland, but also for starting the process of establishing women's football as an event which, in later years, would attract large numbers of spectators and earn a degree of social acceptance.

\section{References}

\section{Primary Sources}

"A Skitish Young Lady at Southend", Barking, East Ham \& Ilford Advertiser, 17 April 1897, 4. https://www.britishnewspaperarchive.co.uk/viewer/bl/0002013/18970417/058/0004. Accessed 15 November 2020.

"Alleged Larceny at a Football Match at Strabane", Belfast Newsletter, 5 June 1896, 7 https://www.britishnewspaperarchive.co.uk/viewer/bl/0000038/18960605/039/0007. Accessed 15 November 2020.

“Association Football, Its Rise and Progress in Dublin", Dublin Evening Telegraph, 4 March $1893,7$. https://www.britishnewspaperarchive.co.uk/viewer/bl/0002093/18930304/112/0007. Accessed 15 November 2020.

“Athletic Jottings", Glasgow Evening News, 21 May 1881, 4. Glasgow Libraries, accessed 15 October 2011

"Ban on Lady Footballers, French XI, Cannot Play in Dublin,” Northern Whig, 1 June 1925, 3. https://www.britishnewspaperarchive.co.uk/viewer/bl/0001542/19250601/045/0003. Accessed 23 November 2020.

“Derry Corporation Bill,” Derry Journal, 3 July 1896, 7. https://www.britishnewspaperarchive.co.uk/viewer/BL/0001123/18960703/083/0007. Accessed 23 November 2020.

Dixie, Lady Florence. “Football for Women”, Pall Mall Gazette, 8 February 1895, 5, 6. https://www.britishnewspaperarchive.co.uk/viewer/bl/0000098/18950208/023/0010. Accessed 23 November 2020

"Evening Sports at Tralee", Kerry Evening Post, 6 May 1893, 3. https://www.britishnewspaperarchive.co.uk/viewer/bl/0001649/18930506/044/0003. Accessed 23 November 2020.

"Female Municipal Franchise Bill," North British Daily Mail, 18 May 1881, 4. Glasgow Libaries Accessed 15 November 2011.

"Five Minute Chat by Willow the Wisp - The Lady Footballers", Blackpool Times, 12 June 1895, 6. Blackpool Heritage Collection, accessed 3 April 2019.

"Football”, East Anglian Times, 30 November 1896, 4. https://www.britishnewspaperarchive.co.uk/viewer/bl/0001727/18961130/141/0007. Accessed 10 October 2020. 
"Football” Northern Whig, 6 November 1878, 8. https://www.britishnewspaperarchive.co.uk/viewer/bl/0000434/18781106/199/0008. Accessed 10 October 2020.

“Football”, Pendleton Times \& Reporter, 14 May 1881, 6. Salford Local History Library, accessed 20 October 2015.

"Former Wallsend FC Manager Dies", Sheilds Daily News, 25 October 1947, 7. https://www.britishnewspaperarchive.co.uk/viewer/bl/0002077/19471025/101/0007. Accessed 24 November 2020.

Healy, T. M. "Letters and Leaders in My Day", Sligo Champion, 23 August 23 1933, 8. https://www.britishnewspaperarchive/viewer/bl/0000432/19330826/099/0008. Accessed 22 September 2020.

"In the Smoke Room," The New Zealand Graphic and Ladies Journal, 19 September 1896, XVII, no. 12, 359. GALE/CC1903567258. Accessed 22 September 2020.

“Irish Lady Footballer's Visit", Dumfries Standard, 5 July 1950, 3. Ewart Library Dumfries, accessed 23 May 2017.

"Ladies as Hockey Players", The Sketch, 22 July 1896, 26. https://www.britishnewspaperarchive.co.uk/viewer/bl/0001860/18960722/023/0026. Accessed 22 October 2020.

"Ladies Chit Chat, by Eva", Richmond \& Rippon Chronicle, 19 July 1890, 6. https://www.britishnewspaperarchive.co.uk/viewer/bl/0002938/18900719/153/0006. Accessed 22 October 2020.

"Ladies Cricket Match", Kildare Observer, 16 July 1887, 5. https://www.britishnewspaperarchive.co.uk/viewer/bl/0001870/18870716/069/0005. Accessed 22 October 2020.

“Lady Footballer", Carrickfurgus Advertiser, 21 August 1891, 2. https://www.britishnewspaperarchive.co.uk/viewer/bl/0001987/18910821/030/0002. Accessed 22 October 2020.

"Ladies Football at Carnarvon", Liverpool Echo, 11 July 1896, 3 https://www.britishnewspaperarchive.co.uk/viewer/bl/0000271/18960711/052/0003. Accessed 22 October 2020.

"Lady Florence Dixie in Glasgow", Glasgow Herald, 22 April 1891, 11. Glasgow Libaries Accessed 18 November 2014.

"Ladies Football", Northern Whig, 5 August 1932, 12. https://www.britishnewspaperarchive.co.uk/viewer/bl/0001542/19320805/324/0012. Accessed 23 November 2020.

“Lady Football Players at Maidenhead", Maidenhead Advertiser, 17 April 1895, 6. https://www.britishnewspaperarchive.co.uk/viewer/bl/0002832/18950417/080/0006. Accessed 10 October 2020.

"Ladies v. Gentlemen, A Surprise for Biggleswade", Biggleswade Chronicle, 1 May 1903, 3. https://www.britishnewspaperarchive.co.uk/viewer/bl/0000752/19030501/055/0003. Accessed 10 October 2020.

“Ladies Football Team v. North-End Juniors", Belfast Newsletter, 24 June 1895, 3. https://www.britishnewspaperarchive.co.uk/viewer/bl/0000038/18950624/013/0003. Accessed 10 October 2020. 
"Ladies at Football", Windsor and Eton Express, 7 December 1895, 3. https://www.britishnewspaperarchive.co.uk/viewer/bl/0000413/18951207/043/0003. Accessed 10 October 2020.

"Lawn Tennis at Norelands", Kilkenny Moderator, 20 September 1879, 3. https://www.britishnewspaperarchive.co.uk/viewer/bl/0002957/18790920/075/0003. Accessed 10 October 20220.

"Lesmahagow", Hamilton Advertiser, 30 August 1873, 2. https://www.britishnewspaperarchive.co.uk/viewer/BL/0000471/18730830/034/0002? browse=true. Accessed 10 October 2020.

“Le Zephyr for New York Theatre”, New York Tribune, 9 December 1907, 7. https://chroniclingamerica.loc.gov/lccn/sn83030214/1907-12-09/ed-1/seq-7/ Accessed 22 September 2020.

“Molly Seaton's XI Win Cup", Northern Whig, 20 August 1932, 3. https://www.britishnewspaperarchive/viewer/bl/0001542/19320820/092/0003. Accessed 23 November 2021.

“Municipal Franchise for Women”, Derry Journal, 17 June 1896, 3. https://www.britishnewspaperarchive.co.uk/viewer/bl/0001123/18960617/047/0003. Accessed 22 October 2020.

“Of Inveresk", Statistical Account of Scotland, XVI, 1795, 19. https://stataccscot.edina.ac.uk/static/statacc/dist/viewer/osa-vol16Parish_record_for_Inveresk_in_the county_of_Edinburgh_in_volume_16_of_accoun t_1/. Accessed 7 May 2021.

"Pancake Day", Meath Herald \& Cavan Advertiser, February 22, 1879, 3. https://www.britishnewspaperarchive.co.uk/viewer/bl/0002910/18790222/016/0003. Accessed 10 October 2020.

"Postponed, Lady Footballers Miss the Boat and Won't Play To-day", Evening Herald, 16 May $1896,5$. https://www.britishnewspaperarchive.co.uk/viewer/bl/0001730/18960516/122/0005 Accessed 23 November 2020.

"Prohibition of the Lady Players", Carlow Sentinel, 28 May 1881, 4. https://www.britishnewspaperarchive.co.uk/viewer/bl/0002909/18810521/057/0004. Accessed 10 October 2020.

"Society in Town And Country", The Social Review, 6 April 1895, 4. https://www.britishnewspaperarchive.co.uk/viewer/bl/0001942/18950406/019/0004. Accessed 23 November 2020.

“The Alexandra College", Mayo Constitution, 2 October 1866, 4. https://www.britishnewspaperarchive/viewer/bl/0001645/18661002/039/0004. Accessed 23 November 2020.

“The British Ladies Club”, The Social Review, 23 May 1896, 5. https://www.britishnewspaperarchive/viewer/bl/0001942/18960523/023/0005. Accessed 23 November 2020.

“The Death of Lady Florence Dixie," Windsor \& Eton Express, 11 November, 1905, 6. https://www.britishnewspaperarchive/viewer/bl/0000413/19051111/100/0006. Accessed 23 November 2020. 
“The Death of Miss Isabella M.S. Tod”, Northern Whig, 9 December 1896, 5. https://www.britishnewspaperarchive/viewer/bl/0000434/18961209/123/0005. Accessed 23 November 2020.

“The Extraordinary Case of Libel, Catch v Shaen”, Clerkenwell News, 2 December 1870, 4. https://www.britishnewspaperarchive.co.uk/viewer/bl/0001000/18701207/033/0004. Accessed 22 October 2020.

“The Family of Lady Florence Dixie”, Edinburgh Evening News, 21 March 1883, 4. https://www.britishnewspaperarchive/viewer/bl/0000452/18830321/054/0004. Accessed 23 November 2020.

"The Football Association, Division 10," Sporting Life, 26 August, 1902, 4. https://www.britishnewspaperarchive/viewer/bl/0000893/19020826/060/0004. Accessed 22 September 2020.

"The Lady Footballers, An Anticipation", The Sketch, 24 October 1894, 33. https://www.britishnewspaperarchive.co.uk/viewer/bl/0001860/18941024/036/0033. Accessed 22 September 2020.

“The Lady Footballers an Interesting Display", Evening Herald, 19 May 1896, 3. https://www.britishnewspaperarchive.co.uk/viewer/bl/0001730/18960519/063/0003. Accessed 22 September 2020.

“The Lady Footballers at Skelmorlie”, Largs \& Millport Weekly News, 23 May 1896, 4. Ayrshire Archives, accessed 22 October 2013.

"The Ladies Football Match in Edinburgh," Scotsman, 9 May 1881, 6. https://www.britishnewspaperarchive.co.uk/viewer/bl/0000540/18810509/167/0006. Accessed 10 October 2020.

“The 'Lady' Football Players”, Irvine Times, 21 May 1881, 5. https://www.britishnewspaperarchive.co.uk/viewer/bl/0002664/18810521/032/000. Accessed 10 October 2020.

“The Lady Footballers, The Drawings", Paisley Daily Express, 6 May 1895, 3. Paisley Heritage Centre, accessed 17 October 2013.

"The Lady Footballers in Belfast - A Novel Spectacle", Northern Whig, 20 June 1895, 8. https://www.britishnewspaperarchive.co.uk/viewer/bl/0000434/18950620/159/0008. Accessed 18 October 2020.

"The Lady Footballers in Belfast, The Match at Cliftonville", Belfast Newsletter, 20 June 1895, 3. https://www.britishnewspaperarchive.co.uk/viewer/bl/0000038/18950620/010/0003. Accessed 18 October 2020.

“The Lady Footballers Defeat a Team of Gentlemen”, Evening Herald, 25 May 1896, 4. https://www.britishnewspaperarchive.co.uk/viewer/bl/0001730/18960525/081/0004. Accessed 22 September 2020.

"Lady Footballers in Belfast", Northern Whig, 17 June 1895, 7. https://www.britishnewspaperarchive.co.uk/viewer/bl/0000434/18950617/153/0007. Accessed 18 October 2020.

“The Lady Footballers in Drogheda", Irish Independent, 30 May 1896, 6. https://www.britishnewspaperarchive.co.uk/viewer/bl/0001985/18960530/144/0006. Accessed 22 September 2020.

"The Lady Footballers' Jerseys: Bogus County Court Summons", Northern Daily Telegraph, 5 April 1900, 3. 
https://www.britishnewspaperarchive.co.uk/viewer/bl/0000652/19000405/071/0003. Accessed 20 November 2020.

"Lady Footballers Mobbed", Wexford People, 3 June 1896, 8. https://www.britishnewspaperarchive.co.uk/viewer/bl/0002344/18960603/101/0008. Accessed 22 September 2020.

“The Lady Footballers", Northern Whig, 22 June 1895, 7. https://www.britishnewspaperarchive.co.uk/viewer/bl/0000434/18950622/173/0007. Accessed 18 October 2020.

"The Lady Footballers", Northern Whig, 24 June 1895, 7. https://www.britishnewspaperarchive.co.uk/viewer/bl/0000434/18950624/147/0007. Accessed 18 October 2020.

"The Lady Footballers - The Match at Wexford Park on Monday", Wexford People, 24 June 1896, 5. https://www.britishnewspaperarchive.co.uk/viewer/bl/0002344/18960624/075/0005. Accessed 22 September 2020.

“The Marquis of Queensberry," Dundee Evening Telegraph, 9 April 1895, 2. https://www.britishnewspaperarchive.co.uk/viewer/bl/0000453/18950409/024/0002. Accessed 24 November 2020.

“The New Women”, Portadown News, 16 May 1896, 8. https://www.britishnewspaperarchive.co.uk/viewer/bl/0002540/18960516/107/0008. Accessed 12 October 2020.

"To the Editor of the Freeman", Freeman's Journal, 12 June 1896, 7. https://www.britishnewspaperarchive.co.uk/viewer/bl/0000056/18960612/038/0007. Accessed 12 October 2020

"What Next?"Belfast Telegraph, 10 May 1881, 3. https://www.britishnewspaperarchive.co.uk/viewer/bl/0001631/18810510/047/0003. Accessed 10 October 2020.

“Women's Football Match”, Carlow Sentinel, 21 May 1881, 4. https://www.britishnewspaperarchive.co.uk/viewer/bl/0002909/18810521/057/0004. Accessed 10 October 2020.

\section{Secondary Sources}

Baker, Michael. Rise of the Victorian Actor. Routledge, 2016.

Beaumont, Caitriona. "Reference to women's place in the home must be removed from Constitution". The Irish Times, 4 October 2018. https://www.irishtimes.com/opinion/reference-to-woman-s-place-in-home-must-beremoved-from-constitution- 1.3650608

Bonnel, Marlyn. "Sarah Grant and the Critical Establishment: [Wo]man's Sake”. Tulsa Studies in Women's Literature 14 (1995): 123-148.

Brennan, Patrick. The Munitionettes: A History of Women's Football in North East England during the Great War. Rowlands Gill: Donmouth Publishing, 2007.

- - . "Nettie Honeyball," Donmouth.co.uk (2014). http://donmouth.co.uk/womens_football/nettie_honeyball.hyml 
Byrne, Helena. "How it all began: the story of women's soccer in sixties Drogheda". Soccer \& Society 18, (26 September 2016). doi: 10.1080/14660970.2016.1230343

- - . "Mapping Irish Football”, The Newsroom Blog, British Library, 11 June 2020. https://blogs.bl.uk/thenewsroom/2020/06/mapping-irish-womens-football.html

Charlton, James and William Thompson. "Croquet; Lore \& Legend”, Oxford Croquet, 2004. http://www.oxfordcroquet.com/history /american/index.asp

Congáil, Ríona Nic. "'Looking on for Centuries from the Sideline": Gaelic Feminism and the Rise of Camogie". Éire-Ireland 48, no. 1 (2013): 168-190. doi:10.1353/eir.2013.0012

Crewe, Steven Lea. Sport Recreation and the Workplace in England, c. 1918 - c. 1970. PhD diss, DeMonfort University, (2014).

"Football Makes History." "Mrs Graham: Promoting the Women's Game." 5 June 2020. https://footballmakeshistory.eu/mrs-graham-promoting-the-womens-game/

Jackson, Alexander. "The Pioneer of Ladies football in Ireland: A Brief History of Mrs Scott”. Playing Pasts, 29 March 2021.

https://www.playingpasts.co.uk/articles/football/the-pioneer-of-ladies-football-inirelanda-brief-history-of-Mrs-Scottpart-on/.

Jenkel, Lisa. “The FA's ban of Women's football 1921 in the contemporary press $-a$ historical discourse analysis". Sport in History, 20 February 2020. doi: 10.1080/17460263.2020.1726441

Lee, James F. The Lady Footballers, Struggling to Play in Victorian Britain. Routledge, 2007.

Mitchell, Andy. "A Case of Mistaken Identity - Emma Clarke and the British Football Club." Scottish Sports History, 24 September 2019. http://www.scottishsportshistory.com/sports-history-news-and-blog/a-case-ofmistaken-identity-emma-clarke-and-the-british-ladies-football-club.html

Moore, Cormac. “The Irish Soccer Split”, History Ireland, 23 no. 6 (November/ December, 2015). https://www.historyireland.com/20th-century-contemporaryhistory/the-irish-soccer-split/.

McAuliffe, Mary. "The Irish Woman Worker and the Conditions of Employment Act, 1936" in "Women: Special Issue" ed Mary Chancy and John Cunningham, Saothar 36 (2011). http://www.jstor.org/stable/23200046.

McCrone, Kathleen. “Class Gender and English Women's Sports c. 1890 - 1914”. Sports History, 18, no 1 (spring 1991).

Parks, Susan M. "Alice Oldham and the admission of women to Trinity College, 1892-1904". Trinity Morning Discourse, 10 May 2004. https://www.tcd.ie/Secretary/FellowsScholars/discourses/discourses/2004_S\%20Park es\%20on\%20A\%200ldham.pdf 
Rix, Kathryn."Women and the Municipal Franchise”, The History of Parliament, 2 August 2019.https://thehistoryofparliament.wordpress.com/2019/08/02/women-and-themunicipal-franchise/.

Saunders, Richard. Beastly Fury: The Strange Birth of British Football. Bantam Books, 2010.

"Secret history of women's football reveals how riots during Auld Enemy clash led to Scotland banning the developing game", Daily Record, 1 September 2013, https://www.dailyrecord.co.uk/news/real-life/secret-history-womens-footballuncovered-2243257 Accessed 3 May 2021.

Walsh, Fionnuala. "We work with shells all day and night", Saothar, Journal of the Irish Labour History Society 42 (2017). http://hdl.handle.net/10197/10075

Williams, Jean. A Beautiful Game International Perspectives on Women's Football. Berg Publishing, 2007.

- - . "Emma Clarke (born 1871) was a lost Lioness." JJ Heritage, 8April 2020. https://www.jiheritage.com/blog/emma-clarke-born-1871-was-a-lost-lioness-apioneering-victorian-football-player-but-much-remains-to-be-known-about-her-life

Wrack, Suzanne. "'We were shocked stunned': 50 Years Since Dundalk v Corinthians Nomads". Guardian, 12 May 2020. https://newstral.com/en/article/en/1151929549/we-were-shocked-fifty-years-since-dundalk-v-corinthians-nomads 